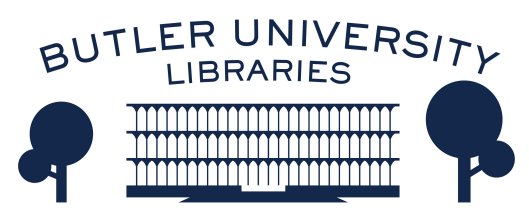

Journal of Hindu-Christian Studies

Volume 12

Article 9

January 1999

\title{
The Love of God in the New Testament and in the Tulsikrt Ramcaritmanas
}

L. Thompson Wolcott

Follow this and additional works at: https://digitalcommons.butler.edu/jhcs

Part of the Religion Commons

\section{Recommended Citation}

Wolcott, L. Thompson (1999) "The Love of God in the New Testament and in the Tulsikrt Ramcaritmanas," Journal of Hindu-Christian Studies: Vol. 12, Article 9.

Available at: https://doi.org/10.7825/2164-6279.1207

The Journal of Hindu-Christian Studies is a publication of the Society for Hindu-Christian Studies. The digital version is made available by Digital Commons @ Butler University. For questions about the Journal or the Society, please contact cbauman@butler.edu. For more information about Digital Commons @ Butler University, please contact digitalscholarship@butler.edu. 


\section{The Love of God in the New Testament and in the Tulsikrt Ramcaritmanas ${ }^{1}$}

\section{Thompson Wolcott}

kamahi nari piyari jimi lobhihi priy jimi dam timi raghunath nirantar priy lagahu mohi ram TDRamayana VII 130

agapetoi, agapomen, allelous, hoti he agape ek tou theou estin, kai pas ho agapon ek tou theou gegennetai kai ginoskei ton theon

NT 1 John $4: 7$

\section{Foreword:}

A study of seemingly similar concepts in different cultures and religions should avoid the temptation simply to equate them or to contrast them. The intention should be to understand them within their own environment, noting their distinctions or resemblances only as these may be needed to sharpen their significance in their own settings, without judging them by criteria external to their settings.

\section{The Intent}

Love, associated with God, is central to the message of the New Testament. Love, associated with God, is fundamental to the message of Tulsi Das in his version of the Ramayan (the Tulsikrtramcaritmanas). The Tulsi Ramayana is the most widely influential scripture for the Hindus of northern India as the New Testament has been for Christians.

The intent of this paper is to note the way the writers of these scriptures, in the historical and religio-social settings in which they wrote, used the language of love available to them in and for the faith messages they wished to convey.
As a lover loves his mistress and a miser loves his wealth, Even so Raghunath be endlessly loved by me

Beloved, let us love one another, for love is from God and he who loves is born of God and knows God.

\section{THE NEW TESTAMENT}

\section{The Setting}

The New Testament was written by many persons, most of whom, if not contemporaries, were at least acquainted with people who had known Jesus or known about him when he lived in Galilee and Judea in the first century of the common era. It was written in order to preserve the story of Jesus and of the faith, fellowship, and mission of the early church and to encourage and counsel Christians who were being persecuted for their faith and were disappointed in the delayed return of Jesus.

The theological background was that of the popular Judaic sect of the Pharisees with its lively expectation of the coming of God's anointed one (Messiah), saturated with a knowledge of the Hebrew scriptures as the word of God. The writers were convinced that Jesus was the expected Messiah through whom the ultimate age was being fulfilled.

\section{The Language of Love}

The principle word for love in the original Greek of the New Testament is agape. This word was thematic in most of the New Testament. The word agape comes from the verb agapao whose root significance was 
"contentment with an object, or delight in that which naturally belongs - as of parents in their children". Scarcely used before Hellenistic times, it was used in the Septuagint translation of the Hebrew scriptures and especially in the Apocrypha, in the book of "Wisdom" for the Hebrew verb 'ahabh and noun, 'ahabhah, for God's love selectively and exclusively for his people.

It became the appropriate word for the early Christian community - whose common scripture was the Septuagint (in Greek) translation of the Hebrew scriptures - for God's love for his people covenanted with them through their faith in Jesus Christ.

\section{Love for others}

The word agape is used in the New Testament mostly for the love of Christians toward one another, a love extending in compassion towards all persons in need, and in forgiveness even towards enemies. It first appears in the Paul writings where it describes the prime virtue and expression of faith and Christian fellowship. It is the dominating concept in the Gospel and the letters "of John". "From God", who "is Love", who is "the Father" of Jesus and his disciples, it is the requisite evidence of a Christian's relationship with fellowbelievers, with God, and with anyone in need. For the later writings of the New Testament, agape love is clearly the accepted norm for Christian living. The noun agape scarcely appears in the three synoptic gospels, indicating their independence from the Paul writings. Nevertheless these gospels tell a story that makes obvious the origin of the Christian emphasis on love in Jesus' conscious relation with God, in his acts of healing and restorative compassion, in many of his parables, in his teaching on forgiveness, on inter-human relations, especially with people in want, in distress, and with the socially rejected and the hostile.

In apocalyptic portions of the New Testament such as "Revelation", the love of God ideal is least used. These are passages which justify believers for their faith and condemn the enemies of their faith as enemies of God's righteousness.

\section{Love from God}

The words agape and agapao are not used as frequently in the New Testament to express God's love. Nevertheless the love expected to prevail among believers is clearly considered to be from God. The emphasis in Hebrew scriptures and in Jewish faith on God's "faithfulness and steadfast love" for His chosen covenant people is inherited by the Christians who are assured, in the New Testament writings, that they are His chosen people. Indeed, "God is love" and "we love because God first loved us" and "God demonstrates his own love for us in this: while we were yet sinners Christ died for us". It is the fact and act of God's love made evident and available through the sacrifice and death of his Son, Jesus Christ, by which the Christian believers become "a new creation", "born from above", and receive "the life of the ages", "living no longer for themselves". It is this love from God that affects the interrelationship with fellow believers, their attitude toward their persecutors, and their action in imitation of Christ toward anyone in need.

The death on the cross of Jesus Christ, as son of God, a divine act in one not-to-berepeated agony of human suffering and humiliation at the hands of men, is looked upon as the ultimate expression of love, God's love for all human creatures.

New Testament faith sees in the crucifixion Christ's challenge of self-giving love which he required of his disciples: "Whoever wills to come with me, let him disown himself and take ùp his cross and follow me." By this love they are to love one another, to show it in acts of compassion to persons in need as they would to Jesus, to extend it even to their persecutors. It holds them together through the Holy Spirit of God in the interim while they wait for the fulfilment of God's rule through the return of Jesus Christ.

\section{Love for God}

Even less frequently are agape and agapao used for human love for God. Yet, when asked for the greatest commandment for the life of the faithful Jesus quotes the Hebrew 
command: to "Love the Lord your God with all your heart and with all your soul and with all your mind" to which he adds the command to love one's neighbour especially anyone in need of caring "as yourself". His own example of love for the "Father" [God] is imitated in Paul's expression of love for God, using the Jewish family intimate word for father, " $a b b a$ ". Paul expresses this intimacy as living "in" ["with" or "in union with"] Christ. All four gospels repeat the challenge to disciples to follow and give their lives for Christ, to carry on his mission to the world. In the John Gospel Jesus invites his disciples to an intimate fellowship with him as is his with "the Father" [God].

\section{The Christian Community}

The harmonizing love of God is the bond of the Christian fellowship, of the believers who "participate together" in the love of God through Jesus Christ. For the nonPauline "letters" of the New Testament this agape is the primal character of the believing community, its "royal law", its "law of liberty". The Spirit of God in a believing community produces a relationship of "love, joy, peace, patience with people, kindness, goodness, faithfulness, gentleness", forbearance, forgiveness, compassion, humility.

In the apocalyptic portions of the New Testament this fellowship anticipates an ultimate great assembling of believers praising God, set over against a body of enemies of believers who will, by their own rejection of Christ and "the saints" be rejected in the end. By refusing the love of God which has been offered to them they exclude themselves from love. They are largely characterized as creatures of greed and antagonism. Sin is the absence of love.

\section{THE RAMAYAN}

\section{The Setting}

The Ramcaritmanas was written by one person, the Brahmin Tulsi Das. It was written during the renaissance of Hindu theism in northern India which was under
Muslim rule.

Using the ancient but extremely popular story of the hero-god Rama, it was written to restore and stimulate the adoration of Rama as the incarnation par excellence of Vishnu but who at the same time is Brahman, the Absolute beyond all description, the impersonal made personal for the sake of His worshipers. By stimulating total devotion (bhakti) to Rama, Tulsi Das hoped to restore stability and harmony to Hindu society which the absence of devotion had been desolating.

The theology of Tulsi Das, who accepted the Hindu pantheon of gods and the theistic worship of Shiva, loosely combined ardent Ramaite theism with assertions of orthodox non-dualism (advaita) modified (as in the crow's philosophy in Book VII) with phrasing in the tradition of Ramanuja's qualified nondualism (visistadvaita).

\section{The Language of Love}

The principal word used for "love" by Tulsi Das was prem (incidentally, the word most used to translate agape in Hindi translations of the New Testament) although many other words are used as well.

The theme of Tulsi's Ramayana is bhakti (adoration) within the discipline of dharma (religious and social duty). The word bhakti is related to the roots bhaj (to divide, share or, as in the Mahabharata, "to love, serve, adore") and to bhag (God, the rich, kind, master). In early use as "distribution, partition" or "that which belongs to", it came to signify "attachment, piety, love, devotion" of the suppliant to his benevolent Lord as, in religious faith, the greatest, most joyful path to liberation [salvation]. For Tulsi Das genuine bhakti is a religious word that is to be applied to the entire religio-social structure of Hinduism in which everyone is to be a suppliant to superiors and benevolent to inferiors. The bhakti relationship is lifted, in his Ramayana, to a high conception of a personal contact with a personal representation of God.

Tulsi Das described the bhakti 
experience in words for affection, intense but usually not erotic. His favourite word for bhakti love, prem, was applied both to the suppliants' approach to God and to God's response. He also freely used many other words, chiefly prti, sneh, rati, moh, choh, anurag daya, krpa, karuna, anugrah, and cognates to describe the loving nature of this relationship.

\section{Love for God}

The principle emphasis on love is, for Tulsi Das, adoration (upasana) for God. Such love is primary because devotion is the necessary approach to God and a loving bhakti, as a spontaneous passion of worship, is pleasing to God. Love describes bhakti. Bhakti, however, describes the love. The love must be an upward motion of a self-acknowledged humble person to a lauded superior. Although it can be a direct experience of God, to be genuine, according to Tulsi Das, it expresses an attitude. of humility that all must use toward their superiors, especially Brahmins and holy men. Only thus can orthodox Hindu society maintain its stability. Above all, bhakti, for Tulsi Das, was overflowing, loving service and honour and duty to God, the supreme, to whom all owe bhakti.

The word prem developed from the Sanskrit root, pri: "gladden, show pleasure to, propitiate". Priya, "dear, beloved", and priti, "pleasure, friendship" are Sanskrit cognates also used frequently in the Tulsi Ramayana. Prem is commonly used for affection (but not for physical passion or lust) between man and woman, husband and wife, friend and friend. In the literature, especially the love poetry, of Tulsi Das's time, it meant a deeply felt affection or romantic or, less often, passionate, love of a man for a woman. In the Ramcaritmanas it is an idealized love as that of a woman for her heroic lover. It is linked with bhakti as "the water of devotion and love". It describes the rapture of the monkey Hanuman's love for his Lord.

The poet piles up as many expressions as possible to denote the devotee's love and attachment for God, including, most frequently, sneh: "deep and lasting attach- ment" like saneh: "with stickiness", rati: "erotic love", moh: desire" (but also used for "delusion"), choh: "affection, kindness", anurag: "affection or attachment as of one in love". These words, used freely, become in Tulsi's poetry symbols of totally absorbed attachment to God.

\section{The love of God}

These words are also used for Rama's love for his worshipers. Central to the Ramcaritmanas message, this affectionateness of Rama is always and only a response to the ecstasy of love and affection on the part of His devotees. The sterling character of Ram, who is frequently described as the enemy of kam (sexual passion) excludes any erotic interpretation.

God's response to the devotee within the theatre of existence (samsara) may be considered an inherent necessity because God is supreme. In the hierarchical pattern of dharma it is the obligation of the strong to help the weak, of the lord to benefit the servant, of the great to be generous to the poor. This is evident in the nobleness and beauty which Tulsi Das always ascribes to Rama. The love of God is his responsive kindliness to his devotees. Rama refuses love and protection to no one who appeals to Him, the religious, certainly, but also anyone, no matter how evil: "Rama is the refuge of all who call on Him". Rama "relieves the distress of his suppliants".

The words most descriptive of Ram's responding love are: Daya and adjective cognates: "mercy, favour" and, with Tulsi Das, "kindliness"; Krpa: "pity, graciousness, kindness"; Karuna: "mercy, compassion, pity, tenderness"; Anugrah: "kindness, favour, indulgence, grace, conferring benefits".

The word anugrah is used to assert the grace of Rama. The greatness of God's love is seen in this, his "grace": "Whoever goes to You receives mercy". The very excellence and effectiveness of Rama's mercy is seen in the fact that all that He does (as Tulsi Das repeatedly reminds reader and hearer) is without selfish motive or intent. $\mathrm{He}$ has no need to initiate any act of love or to respond to human devotion which $\mathrm{He}$ does through 
Maya as a sport or game (lila) because $\mathrm{He}$ is in reality the passionless Supreme Spirit, the all-pervading Absolute, the purposeless, actionless Brahman. Yet He does take on bodily form to be available to and to cherish His worshipers. This responding anugrah increases the rapture of the devotee.

His mercy is such that $\mathrm{He}$, alone being free of Maya (which is His own power) that deludes even Brahma and Shiva, also frees the true loving worshiper from Maya's delusion and from karma's fetters. Yet this unmotivated act, this holy lake of the deeds of Rama (Ramcaritmanas), occurs again and again through the eons purely to rescue true worshipers.

\section{Love for one another}

These words of divine love are the traditional attributes applied to Rama, Krishna, and Shiva in bhakti literature. They are commonly used in India for the appropriate response to supplication made by a person's inferiors. Such love from God must be reflected in the kindly generosity of Rama's devotees to their inferiors. Love for others within the dharma of a hierarchical but religious society is a result of bhakti to Rama, for every worshiper will be reverently and gently subservient to all superiors as to God, and be benevolent and kindly to suppliant inferiors as is God. In this way bhakti holds society in balance and stability. This is the thesis of Tulsi Das.

Moreover, love for God detaches the devotee from attachment to things. It frees the devotee from lasciviousness, greed, ambition, lust for power, from pride, passion, selfishness, sorrow. Such attachments are the source of strife. Thus, bhakti promotes peace and contentment.

\section{The Hindu Community}

Tulsi Das portrays the ideal consequence of a society of people practising bhakti love: an atmosphere of goodwill, a community that lives in joyful harmony. In this religious social milieu pre-eminence is given by Tulsi Das to the Brahmins and the "saints". It is to them that bhakti reverence is especially to be shown and it is holy people who especially extend divine love without partiality to others, to those who are helpless and in need. This kind of society Tulsi Das wished to promote with his glowing accounts of Ram Raj (Rama's rule or kingdom).

Thus it is thoroughly implied (in Tulsi's story of Rama's conquest over evil forces who themselves sometimes are saved by calling on Rama's name) that bhakti love forms a linkage of love in the ideal society.

\section{CONCLUSION}

Addressing the growing but persecuted community of Christians, the New Testament writers, with few exceptions, present the love of God as the norm for their relationships.

Thoroughly committed to the worship of Rama, Tulsi Das seeks to arouse his readers and hearers to an adoration that is a rapturous love for God, a glowing love that dominates the devotee and restores the atmosphere of an idealized potential, the golden age of the rule of Rama, the Ram $R a j$. He paints a picture of the adorable one as completely benevolent, kindly, gracious.

In the New Testament, agape love is from God. In the Ramcaritmanas, God's love is a divine response to the entreaties of the devout distressed by demons who are tokens of increased evil and religious neglect.

Mercy in the Ramayana is God's enabling those absorbed in loving bhakti to supersede the influence of Maya and to escape the controls of karma. Mercy in the New Testament is a characteristic of God to be imitated by believers in human relationships.

In the New Testament, grace is God's love empowering the faithful to be and do what would otherwise be beyond their strength or ability. For Tulsi Das, God's grace is that, without benefit to Him, the power of His very name gives light and liberation from existence (samsara) to all who repeat the name: "Take the name of Ram on your lips and it will, like a lamp in the doorway, give light to all that is within and without". Meditative repetition of the 
name of Rama brings Rama into the heart of the devotee, making the Impersonal personal, bringing unutterable joy to the devotee.

In Tulsi's Ramayana prem bhakti is an ecstasy of joy and praise in the presence of Rama's amiable beauty and liberating benevolence: "Without love no one can meet Rama". In the New Testament, especially in the John writings and in the Paul writings, agape includes an intimate communion relationship with Christ: "Remain in me, and I in you", "we are God's children".

For the New Testament agape love is effective through the actual (non-docetic) suffering and self-giving act of Jesus Christ. For Tulsi Das bhakti love draws the Ram figure into the theatre of illusion where $\mathrm{He}$ undergoes fierce struggle with Ravana and his demonic hordes to save His devotees who can be confident, however, that His Absolute Brahman reality is untouched.

In sum, devoted love for God in the Rama incarnation and the assurance of God's beautifully loving and saving response are the essence of the Tulsi Das Ramayana. For the New Testament God's love for all his human creatures, His suffering to make it available, and a commission to share it are at the heart of its message. For each scripture, the love each describes is effective in human relationships.

\section{Afterword:}

No one, I think, can read the Ramcaritmanas without being caught up in the glow of its fervent love for God in a personally perceived form. No one, I think, can read the New Testament without being stirred by its call to divinely inspired, enduring love in human relationships.

\section{Note}

1. Principal sources used for the study of the Ramayana of Tulsi Das were:

The Bombay text, edited by Rameshvar Bhatt;

A Varamasi text edited by Ramjasan;

The Nagari Pracarani Sabha text edited by Sambhu Narayan Caube;

A text by Gita Press of Gorakhpur with comments by Hanuman Prasad Poddar;

Manas Sabd Sagar compiled by Badridas Agraval (Calcutta; Mudrak Manadal Press); Tulasi Sabd Sagar compiled by Bholanath Tiwari (Allalabad, Hindustani Ekedami). 